\title{
Genetic diversity among natural populations of Mandevilla velutina
}

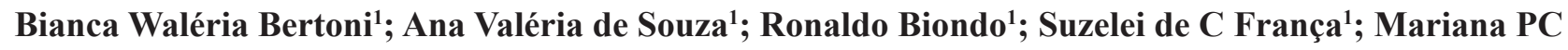 \\ Telles$^{2}$; Ana Maria S Pereira ${ }^{1}$ \\ ${ }^{1}$ UNAERP-Dept ${ }^{\circ}$ Biotecnologia de Plantas Medicinais, Av. Costábile Romano 2201, 14096-900 Ribeirão Preto-SP; ${ }^{2}$ Universidade \\ Católica de Goiás-Lab. Genética e Biodiversidade, Goiânia-GO; apereira@unaerp.br
}

\begin{abstract}
Mandevilla velutina (Mart. Ex Stadelm) Woodson (Apocynaceae) is an endemic species in the Cerrado (Brazilian Savannah), whose alcoholic extracts and root infusions are extensively used in the popular medicine to treat inflammatory diseases and against snake bites. Currently, this species has been pointed out as crucial in conservation programs. Therefore, studies on its genetic diversity, as well as the development of methodology for in vitro conservation in germplasm banks are imperative to avoid its extinction. The objective of this work was to investigate the intra- and inter-populational genetic variability of $M$. velutina to enhance the representativeness of germplasm banks. To this aim, we used RAPD molecular markers. The analysis of molecular variance (AMOVA) indicated that the intra-populational $(81.25 \%)$ was higher than the inter-populational $(18.75 \%)$ variability, which was confirmed by the Nei's Diversity Index. The PHI ${ }_{\text {st }}(0.188)$ and $\mathrm{q}_{\mathrm{P}}(0.1586)$ values of genetic variation indicated high population structuring. There seems to be no direct correlation between geographic distances and genetic similarity among the three studied populations.
\end{abstract}

Keywords: Mandevilla velutina, medicinal plant, extinction risk, molecular markers.

\begin{abstract}
RESUMO
Diversidade genética em populações naturais de batata infalível

A batata-infalível (Mandevilla velutina (Mart. Ex Stadelm) Woodson, Apocynaceae) é uma espécie endêmica do Cerrado, amplamente utilizada na medicina popular na forma de extrato alcoólico ou infusões do sistema subterrâneo. A planta é utilizada no tratamento de processos inflamatórios e em acidentes com serpentes. Atualmente, esta espécie é considerada prioritária em programas de conservação e, por isso, estudos de diversidade genética e métodos de conservação in vitro em bancos de germoplasma são relevantes para evitar sua extinção. O objetivo deste trabalho foi estudar a variabilidade genética em diferentes populações de batata infalível por meio de marcador molecular RAPD visando fornecer subsídios para a conservação da espécie em bancos de germoplasma. A análise molecular de variância (AMOVA) revelou que a variabilidade dentro das populações $(81,25 \%)$ foi maior que entre populações $(18,75 \%)$. Esses resultados foram confirmados pelo Índice de diversidade de Nei. As estimativas de variação de $\operatorname{PHI}_{\mathrm{ST}}(0,188)$ e $\mathrm{q}_{\mathrm{p}}(0,1586)$ indicaram alta estruturação populacional. Não foi observada uma relação direta entre as distâncias genéticas e geográficas das três populações estudadas.
\end{abstract}

Palavras-chave: Mandevilla velutina, planta medicinal, risco de extinção, marcador molecular.

(Recebido para publicação em 30 de abril de 2009; aceito em 9 de abril de 2010) (Received on April 30, 2009; accepted on April 9, 2010)

$\mathrm{D}$ NA analysis using molecular markers, such as RAPD (Random Amplified Polymorphic DNA), has been successfully used to study the genetic diversity of many plant species (Rout et al., 1998; Piola et al., 1999; Gauer \& Cavalli-Molina, 2000; Bittencourt, 2000; Ciampi, 2001; Sales et al., 2001; Souza et al., 2004; Gonçalves et al., 2008; Gonçalves et al., 2009). RAPDs are valuable in studies of genetic mapping, population genetics, molecular systematics, genotype fingerprinting and marker-assisted selection in plant and animal breeding. Among its advantages, RAPDs are a low cost marker and provide an unlimited number of highly polymorphic fragments, which cover nearly the entire genomic DNA(Ferreira \& Grattapaglia, 1998). Since they are not species-specific markers, RAPDs are especially suitable for the preliminary assessment of the genetic diversity in populations and/or species which little is known from in the scientific point of view, as it is the case of Tibouchina papyrus (Telles \& Soares, 2007). RAPDs are PCR-based markers developed by Williams et al. (1990) that offer the opportunity to generate a large amount of polymorphism of DNA fragments spread throughout the genome, without requiring prior knowledge of the DNAsequence target, or of species-specific primers. The technique involves the simultaneous amplification of several anonymous regions in the genome using arbitrary primer-sequences for PCR (Ferreira \& Grattapaglia, 1998).

The genetic characterization of populations by means of molecular markers is based on the evaluation of differences in genetic patterns and the identification of specific bands. The different markers currently available allow us to access a considerable level of polymorphism, thus enabling the analysis of genetic variability within and between populations (Alfenas et al., 2006). The analysis of genetic diversity makes it possible to select genotypes of interest for further conservation in germplasm banks, aiming at preserving the genetic variability present in natural populations and decelerating the pace of genetic erosion.

In Brazil, especially in the Brazilian Savannah, numerous species have been listed as priorities in conservation programs and studies of genetic diversity, because of the high degree of endemism and devastation that this biome faces. In this context, we found the species 
Mandevilla velutina (Mart. Ex Stadelm) Woodson, whose natural populations are shrinking to alarming levels. That spices is used in popular medicine as alcoholic extracts or infusions of the underground part to treat inflammatory processes and accidents with poisonous snakes (Almeida et al., 1998).

Our objective was to study the genetic variability of Mandevilla velutina to provide useful information for the ex situ conservation of is natural populations.

\section{MATERIAL AND METHODS}

Mandevilla velutina leaves were collected in the municipalities of São Carlos, Santa Catarina State, Pedregulho, São Paulo State, and Araxá, Minas Gerais State, Brazil, comprising in total 67 individuals. Leaves of each accession were packed separately, in indentified falcon tubes containing blue silica gel, and then stored at $-20^{\circ} \mathrm{C}$, until DNA extraction. Plants were collected at random and the geographical location data were mapped by the Global Positioning System (GPS). An exsiccate was deposited in the Herbarium of Medicinal Plants, University of Ribeirão Preto (HPMUNAERP, Ribeirão Preto, São Paulo State) under the number №. 0013.

Young leaves were used for genomic DNA extraction, according to Doyle \& Doyle (1987). DNA was purified by re-suspension in $500 \mu \mathrm{L} 1 \mathrm{M} \mathrm{NaCl}$ solution and incubation in water bath at $65^{\circ} \mathrm{C}$ for 5 minutes. Next, DNA was kept at $4^{\circ} \mathrm{C}$ for 30 minutes and centrifuged at 12,000 rpm for 5 minutes. The supernatant containing the DNA was transferred to another tube and 350 $\mu l$ of Isopropanol were added. After a 10-minute rest, the DNA precipitated and was centrifuged at 12,000 rpm for 5 minutes. Then, the pellet was washed twice with $70 \%$ ethanol, followed by centrifugation at $12,000 \mathrm{rpm}$ for 5 min. After drying for one hour at room temperature, the pellet was resuspended in $100 \mu \mathrm{l}$ of Milli-Q water. For quantification, DNA was applied to an agarose gel 1\% (w/v), stained with Ethidium bromide and illuminated under ultraviolet light. Bands were compared to standard DNA (lambda phage) of known concentrations.

To standardize the RAPD protocol, DNA samples were evaluated initially with 100 primers (Operon Technology and Life Biosynthesis Incorporated), from which 11 were selected (Table 1). Only reproducible bands in different analysis were considered. Weak amplifications that eventually occurred were excluded. Control samples, containing all reaction products except DNA were evaluated to check for non self-amplification or presence of contaminants. At the end, we developed a matrix of binary data containing the absence or presence of amplified fragments.

The standardization of the PCR parameters for $M$. velutina produced the following RAPD reaction: $3 \mu \mathrm{L}$ of Tp 10X; $3 \mu \mathrm{L}$ of dNTPs $2.5 \mathrm{mM} ; 1.8$ $\mu \mathrm{L}$ of $\mathrm{MgCl}_{2} 25 \mathrm{mM} ; 7 \mu \mathrm{L}$ of primers $10 \mathrm{ng} \mu \mathrm{L}^{-1} ; 0.2 \mu \mathrm{L}$ of Taq polymerase 5 $\mathrm{u} \mu \mathrm{L}^{-1}$ and $2 \mu \mathrm{L}$ of DNA $5 \mathrm{ng} \mu \mathrm{L}^{-1}$ in a final volume of $30 \mu \mathrm{L}$. The amplification was performed in a thermal-cycler as follows: two cycles at $94^{\circ} \mathrm{C}$ for 2 minutes, one cycle at $37^{\circ} \mathrm{C}$ for 1 minute, one cycle at $72^{\circ} \mathrm{C}$ for 2 minutes and 33 cycles at $94^{\circ} \mathrm{C}$ for 10 seconds, $40^{\circ} \mathrm{C}$ for 20 seconds (annealing temperature) and $72^{\circ} \mathrm{C}$ for 2 minutes.

For the analysis of genetic variability, the binary data (presence or absence of bands) obtained from RAPD, were used to estimate the allele frequencies based on the correction proposed by Lynch \& Milligan (1994). Then, a descriptive analysis of the total variability was carried out by calculating the percentage of polymorphic loci, assuming the Hardy-Weinberg equilibrium. We used the software POPGENE (Yeh et al., 1999). Nei's genetic distances (1973, 1978) were used in the cluster analysis, carried out by the UPGMA (unweighted pair-group method with arithmetic means) method (Legendre \& Legendre, 1998).

The variance among and within populations was studied also by AMOVA (Analysis of Molecular Variance), as proposed by Excoffier et al. (1992). We used TFPGA (Miller, 1997), AMOVA-PREP 1.01 (Miller, 1998) and WINAMOVA 1.04 (Excoffier, 1992). Allele frequencies were also submitted to analysis of variance (Weir 1996; Telles, 2000).

\section{RESULTS AND DISCUSSION}

Among the primers evaluated, we selected those that produced bands of high intensity and that revealed a high degree of polymorphism (Table 1). The 11 primers selected produced 111 bands, mostly polymorphic in the three populations, as exemplified by primer OP11 for twenty-six accessions (Figure 1). The lowest and highest numbers of bands per primer were respectively seven and 15 (Table 1).

The results of the genetic variability obtained with different statistical estimates indicated that RAPDs provided a consistent genetic analysis of the three Mandevilla velutina natural populations studied. Considering the 67 individuals assessed, the total percentage of polymorphic loci was $81.08 \%$. The population from Araxá comprised the highest percentage of polymorphic loci (77.48\%), followed by the populations of Sacramento (64.86\%) and Pedregulho (49.55\%) (Table 2). The AMOVA based on RAPD markers showed that most of the genetic variability was in the intrapopulational $(81.25 \%)$ when compared to interpopulational level $(18.75 \%)$, which is an interesting result, since $M$. velutina is a cleistogamic species. PHI $_{\text {st }}$ value was $0.188(\mathrm{p}<0.001)$, indicating a significant structuring of the genetic variability in these populations (Table 3). The analysis of variance for allele frequencies, which was used to evaluate the structure of the genetic variability in the populations of $M$. velutina, showed $\mathrm{q}_{\mathrm{p}}$ values ranging from 0.027 to 0.2833 , with a global value of 0.1586 (IC at $95 \% 0.2251$ and 0.1037 ).

Wind is the main agent of seed dispersal in M. velutina, which favors a long distance spread, especially because seeds are light and crowned with a dense apical tuft of 15-20 mm-long trichomes (Almeida et al., 1998). According to Loveless \& Hamrick (1984), seed dispersal by the wind increases the variation within populations, but this depends also on the wind speed and on characteristics of the seeds. Migration 
Table 1. Primers and RAPD bands obtained in the analysis of 67 accessions of Mandevilla velutina (primers e bandas de RAPD obtidas na análise de 67 indivíduos de batata infalível). Ribeirão Preto, UNAERP, 2007.

\begin{tabular}{clrcc}
\hline \multirow{2}{*}{ Primers } & \multirow{2}{*}{ Sequences $(\mathbf{5}, \boldsymbol{3}$ ') } & \multicolumn{3}{c}{ Number of bands } \\
\cline { 3 - 5 } & CAGGCCCTTC & 9 & Polymorphic & Monomorphic \\
\hline 1 & TGCCGAGCTG & 12 & 12 & 4 \\
3 & AGGTGACCGT & 8 & 7 & 0 \\
4 & GTCCACACGG & 9 & 8 & 1 \\
5 & CAGCACCCAC & 10 & 10 & 1 \\
6 & TCGCCCAGTG & 7 & 6 & 0 \\
7 & TGCCGAGCTG & 8 & 7 & 1 \\
8 & GAATATGGGTGCGCTCTG & 8 & 8 & 1 \\
9 & AGGGGTCTTG & 13 & 10 & 3 \\
10 & AAGGGATTGTTCTGTTCGCTG & 15 & 11 & 4 \\
11 & TGATTACACCAATTACCACG & 12 & 8 & 4 \\
\hline & Total & 111 & 92 & 19 \\
\hline
\end{tabular}

Table 2. Basic descriptive statistics of three populations of Mandevilla velutina, assuming the Hardy-Weimberg equilibrium (parâmetros descritivos básicos de três populações de batata infalível, assumindo o equilíbrio de Hardy-Weinberg). Ribeirão Preto, UNAERP, 2007.

\begin{tabular}{lcc}
\hline Population & Sample average size $(\overline{\mathbf{n}})$ & Polimorphic loci (\%) \\
\hline Pedregulho & 10 & 49,55 \\
São Carlos & 16 & 64,86 \\
Araxá & 41 & 77,48 \\
\hline Total & 67 & 81,08 \\
\hline
\end{tabular}

Table 3. Inter- and intra-populational AMOVA for 111 individuals of Mandevilla velutina (AMOVA entre e dentro de populações para 111 indivíduos de batata infalível). Ribeirão Preto, UNAERP, 2007.

\begin{tabular}{lccccccc}
\hline $\begin{array}{l}\text { Sources of } \\
\text { variation }\end{array}$ & DF & SQ & MSD & $\begin{array}{c}\text { Components } \\
\text { of Variance }\end{array}$ & $\begin{array}{c}\text { Total } \\
\text { variation } \\
(\mathbf{\%})\end{array}$ & P & $\begin{array}{c}\text { Pairwise } \\
\text { PHI }_{\text {ST }}\end{array}$ \\
\hline $\begin{array}{l}\text { Among } \\
\text { populations }\end{array}$ & 2 & 142.22 & 71.11 & 3.37 & 18.75 & $<0.001$ & 0.188 \\
\hline $\begin{array}{l}\text { Within } \\
\text { populations }\end{array}$ & 61 & 890.84 & 14.60 & 14.60 & 81.25 & - & - \\
\hline Total & 63 & $1,033.06$ & & & & & \\
\hline
\end{tabular}

DF: degrees of freedom (graus de liberdade); SQ: sum of squares (soma de quadrados); MSD: mean square deviations (soma dos quadrados médio); P: levels of significance of the estimates of genetic variation after 1000 permutations (nível de significância da estimativa de variação genética após 1000 permutações).

of few seeds over long distances can prevent populations from diverge. This information corroborates the results currently obtained for M. velutina, as most of the genetic variability was identified within populations $(81.25 \%)$. In this case, it is possible to infer that populations arise from different plants. However, to confirm this statement, it would be interesting to carry out a more refined analysis of gene flow via pollen the species reproduction and biology (Solé-Cava, 2001; Solferini \& Selivon, 2001; Fernandes-Matioli, 2001). For estimating $\mathrm{PHI}_{\mathrm{st}}$ significantly different from zero, values greater than 0.05 were considered as indicators of high population structure and vice-versa (Solé-Cava, 2001). Thus, as the estimate of variation $\mathrm{PHI}_{\text {st }}$ was 0.188 , higher than the limit established, we concluded that there was a high population structure. This result was confirmed by analyzing the pattern of spatial variation based on the Pearson correlation coefficient ( $r$ ) between the matrices of Nei's genetic distances and the geographical distances between populations. The $\mathrm{r}$ value for the matrices was 0.80227 , which is a high magnitude.

According to Solferini \& Selivon (2001), genetic distances are measures of the divergence between populations based on genotypic frequencies. When the genetic distances among the sampled populations were analyzed, we observed variations between 0.308 (the lowest value, recorded between the populations from Pedregulho and São Carlos) and 0.744 (the highest value, estimated between the populations from São Carlos and Araxá). The populations from Pedregulho and Sao Carlos, although genetically closer, are more geographically distant from each other. Thus, it appears that there is no direct relationship between genetic and geographical distances among the three $M$. velutina populations 


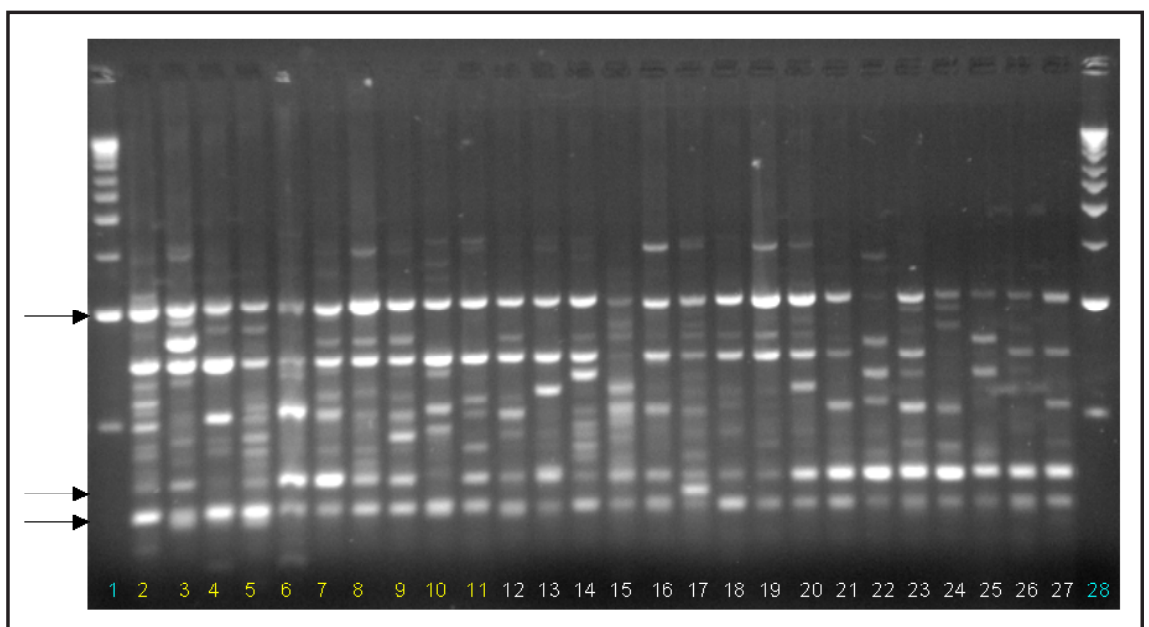

Figure 1. RAPD profile of natural populations of Mandevilla velutina produced by primer 11 (perfil molecular de bandas RAPD de populações naturais de batata infalível obtido com o primer 11). Ribeirão Preto, UNAERP, 2007.

* Lanes 2 to 27 correspond to ten and 16 individuals from the municipalities of Pedregulho and São Carlos, respectively (raias 2 a 27 correspondendo a dez e 16 indivíduos dos municípios de Pedregulho e São Carlos, respectivamente); Arrows indicate monomorphic bands (as setas indicam bandas monomórficas); Molecular ladders of $100 \mathrm{~Kb}$ in lanes 1 and 28 (marcadores de peso molecular de $100 \mathrm{~Kb}$ nas raias 1 e 28).

studied, as observed before for catuaba (Anemopaegma arvense) (Batistini, 2006).

Populations of endangered species are often structured. This is due to the environmental degradation, which promotes the formation of refuges (fragments), where small populations of these species persist without exchanging genes with individuals from not disturbed areas. Therefore, the analysis of the pattern of spatial variation is very important for conservation studies, because, if an endangered species in a given area appears structured, the conservation strategy should be to preserve the diversity of the species, preventing losses of local adaptations in the event of mixtures (Solé-Cava, 2001). Zimback et al. (2004) stress that the study of the genetic structure of natural populations from native species is important because it allows inferences about their current status and proposes measures to either maintain the conservation condition or to recover the genetic potential of the species. The figures of the statistical estimates presently obtained for $M$. velutina show the relevance of this work and point for the need to initiate conservation program for the species.

\section{REFERENCES}

ALFENAS AC. 2006. Eletroforese e marcadores bioquímicos em plantas e microorganismos. Viçosa: Editora UFV. 627p.

ALMEIDA SP; PROENÇA CEB; SANO SM; RIBEIRO JF. 1998. Cerrado: Espécies vegetais úteis. Planaltina: EMBRAPA-CPAC. $464 \mathrm{p}$.

BATISTINI AP. 2006. Diversidade morfológica, genética e química de populações naturais de Anemopaegma arvense (Vell.) Stellf. Jaboticabal: UNESP. 96p (Tese doutorado).

BITTENCOURT JVM. 2000. Variabilidade genética em populações naturais de Maytenus ilicifolia por meio de marcadores RAPD. Universidade Federal do Paraná. 58p (Tese mestrado).

CIAMPIAY. 2001. Uso de marcadores moleculares nos estudos de genética de populações de espécies florestais. In: III SIMPOSIO DE RECURSOS GENÉTICOS PARAAMÉRICA LATINA E CARIBE. Anais... Londrina, IAPAR. p. 19-22.

DOYLE JJ; DOYLE JL. 1987. Isolation of plant DNA from fresh tissue. Focus 12: 13-15.

EXCOFFIER L; SMOUSE PE; QUATTRO JM. 1992. Analysis of molecular variant inferred from metric distances among DNA haplotypes: application to human mitochondrial DNA restriction dada. Genetics 131: 479-491.

EXCOFFIER L. WINAMOVA 1.04: Analysis of Molecular Variance. 1992. (Programa para computadores livre distribuído pelo autor). Disponível em: www.tien.utk.edu/ gross/ WWW pt2d.html. Acessado em fevereiro de 2005 .

FERNANDES-MATIOLI FM. 2001. Genealogia e o processo de coalescência. In: MATIOLI SR. (eds) Biologia Molecular e Conservação. Ribeirão Preto: Editora Holos, p.162-171.

FERREIRA ME; GRATTAPAGLIA D. 1998. Introdução ao uso de marcadores moleculares em análise genética. Brasília: EMBRAPACENARGEN. 220p.

GAUER L; CAVALLI-MOLINA S. 2000. Genetic variation in natural population of maté (Ilex paraguariensis A. St.-Hil., Aquifoliaceae) using RAPD markers. Heredity 84: 647-656.

GONÇALVES LSA; RODRIGUES R; AMARAL JÚNIOR AT; KARASAWA M, SUDRÉ CP. 2008. Comparison of multivariate statistical algorithms to cluster tomato heirloom accessions. Genetics and Molecular Research 7: 1289-1297.

GONCALVES LSA; RODRIGUES R; AMARAL JÚNIOR AT; KARASAWA M, SUDRÉ CP. 2009. Heirloom tomato gene bank: assessing genetic divergence based on morphological, agronomic and molecular data using a Ward-modified location model. Genetics and Molecular Research 8: 364-374.

LEGENDRE P; LEGENDRE L. 1998. Numerical Ecology. Elsevier: Amsterdam.

LOVELESS MD; HAMRICH JL. 1984. Ecological determinants of genetic structure in plant populations. Annual Review and Systematics 15: 65-95.

LYNCH M; MILLIGAN BG. 1994. Analysis of population genetic structure with RAPD markers. Molecular Ecology 3: 91-99.

MILLER MP. TFPGA 1.03: 1997. Tools for population genetics analyses (Programa para computador livre distribuído pelo autor) Disponível em $<$ www.marksgeneticssoftwear. net/tfpga.htm $>$. Acessado em fevereiro de 2005.

MILLER MP. AMOVA-PREP 1.01: 1998. A program for preparation of AMOVA input from dominant-marker of raw data (programa para computador livre distribuído pelo autor) Disponível em $<$ www.marksgeneticssoftwear. net/amovaprep.htm>. Acessado em fevereiro de 2005.

NEI M. 1973. Analysis of gene diversity in subdivided populations. Proceedings of the National Academy of Sciences of the United States of America 70: 3321-3323.

NEI M. 1978. Estimation of average heterozygosity and genetic distance from a small number of individuals. Genetics 89: 583-590.

PIOLA F; ROHR R; HEIZMANN P. 1999. Rapid detection of genetic variation within and among in vitro propagated cedar (Cedrus libani Loudon) clones. Plant Science 141: 159-163.

ROUT GR; DAS P; GOEL S; RAINA SN. 1998. Determination of genetic stability of micropropagated plant of ginger using Random Amplified polymorphic DNA(RAPD) markers. Botanical Bulletin Academia Sinica 39: 23-27.

SALES E; NEBAUER SG; MUS M; SEGURA J. 2001. Population genetic study in the Balearic endemic plant species Digitalis minor (Scrophulariaceae) using RAPD markers. American Journal of Botany 88: 1750-1759.

SOLÉ-CAVAAM. 2001. Biodiversidade molecular e genética da conservação. In: MATIOLI SR. (ed) Biologia Molecular e Conservação. Ribeirão Preto: Editora Holos, p.172-192.

SOLFERINI VN; SELIVON D. 2001. 
Polimorfismos de isoenzimas. In: MATIOLI SR. (ed) Biologia Molecular e Conservação. Ribeirão Preto: Editora Holos, p.139-142.

SOUZA LMFI; KAGEYAMA PY; SEBBENN AM. 2004. Estrutura genética em populações fragmentadas de Chorisia speciosa St. Hil (Bombacaceae). Scientia Forestalis 65: 70-79.

TELLES MPC. 2000. Diversidade genética e estrutura populacional de cagaiteira (Eugenia dysenterica DC.) do sudeste de Goiás. Goiânia: Escola de Agronomia e Engenharia de Alimentos - Universidade Federal de Goiás,
$129 \mathrm{p}$ (Tese mestrado).

TELLES MPC; SOARES TN. 2007. DNA fingerprinting no estudo de populações de plantas do cerrado. In: PEREIRA AMS (ed). Recursos Genéticos e Conservação de Plantas Medicinais do Cerrado. Ribeirão Preto: Legis Summa Ltda, p. 109-145.

WEIR BS. 1996. Genetic Data Analysis II. Sunderland: Sinauer Associates.445p.

WILLIAMS JGK; KUBELIK AR; LIVAK KJ; RAFALSKI JA; TINGEY SV. 1990. DNA polymorphism amplified by arbitrary primers is a useful genetic markers. Nucleic Acids
Research 18: 6531-6535.

YEH FC; YANG R; BOYLE T. 1999. POPGENE 1.32: Population Genetic Analysis. Programa para computador livre distribuído pelos autores. Disponível em: <ftp://ftp.microsoft. $\mathrm{com} /$ Softlib/MSLFILES/HPGL.EXE $>$. Acesso em: 25/02/2002.

ZIMBACK L; MORI ES; KAGEYAMA PY; VEIGA RFA; MELLO JUNIOR JRSM. 2004. Estrutura genética de populações de Trichillia pallida Swarts (Meliaceae) por marcadores RAPD. Scientia Forestalis 65: 114-119. 